\title{
HILANGNYA SENDI DEMOKRASI DAN OTONOMI DAERAH MELALUI KORPORATOKRASI RUU OMNIBUS LAW
}

\section{Adithya Tri Firmansyah ${ }^{1}$, Ema Sarila Sinaga ${ }^{2}$, Fenia Aurully Aisyah ${ }^{3}$}

1Fakultas Hukum, Universitas Widyagama Malang. E-mail : adithyatfr07@yahoo.com ${ }^{2}$ Fakultas Hukum, Universitas Widyagama Malang ${ }^{3}$ Fakultas Hukum, Universitas Widyagama Malang

\begin{abstract}
ABSTRAK
Salah satu faktor yang menghambat peningkatan iklim investasi di Indonesia disebabkan karena permasalahan regulasi. Pemerintah tengah melakukan berbagai upaya dalam mengejewantahkan kesejahteraan rakyat, sebagaimana paradigma pancasila. Pemerintah berupaya meningkatkan pertumbuhan ekonomi melalui investasi. Dalam implementasinya pemerintah mengagas Rancangan Undang-Undang Omnibus Law yang dengan alasan guna memangkas dan menyederhanakan berbagai regulasi yang dinilai sudah terlalu banyak dan tumpang tindih. Terdapat 8.451 aturan di tingkat pusat dan 15.985 peraturan daerah. Dimana hal tersebut membuat Pemerintah terkekang dan terbatas ruang geraknya sehingga kecepatan pemerintah dalam mengambil keputusan menjadi terlambat dan kurang tepat. Bagi Pemerintah Omnibus law memiliki tujuan untuk mendorong pertumbuhan ekonomi nasional. Namun terjadi polemik dalam proses pembentukan RUU Omnibus Law ini. Beragam penolakan dari berbagai elemen, utamanya masyarakat. RUU Omnibus Law yang menjadi sorotan ialah Cipta kerja kemudian lingkungan hidup dan juga prinsip otonomi daerah yang coba diganggu. Titik masalah dari produk hukum Omnibus Law ini adalah tidak mencerminkan partisipasi masyarakat.
\end{abstract}

ARTICLE INFO

Kata Kunci:

Korporatokrasi;

Demokrasi; Omnibus

Law

Cite this paper:

Adithya Tri

Firmansyah, E. S. S. F. A.

A., 2020. Hilangnya

Sendi Demokrasi dan

Otonomi Daerah

Melalui Korporatokrasi

RUU Omnibus Law.

Widya Yuridika: Jurnal

Hukum, 3(2).

\section{PENDAHULUAN}

Hukum sejatinya tidak dapat dilepaskan dari kehidupan manusia. Pernyataan ini juga dipertegas oleh adagium Marcus Tullius Cicero (106-43 SM) yakni Ubi Societas Ibi Ius yang berarti dimana ada masyarakat maka disitu ada hukum. Tentu hal ini menjadikan alasan bahwa pentingnya peranan hukum sebagai sebuah aturan main dalam hidup dan kehidupan manusia. Secara garis besar, hukum pada dasarnya memiliki beberapa fungsi dalam kehidupan masyarakat, antara lain: Pertama, sebagai standard of conduct yakni sandaran atau ukuran tingkah laku yang harus ditaati oleh setiap orang dalam bertindak serta dalam melakukan hubungan satu dengan lain; Kedua, sebagai as a tool social 
engeneering, yakni sarana atau alat untuk mengubah masyarakat kearah yang lebih baik, baik secara pribadi maupun dalam hidup masyarakat; ketiga : sebagai as a tool of social control, yakni sebagai alat untuk mengontrol tingkah laku dan perbuatan manusia agar mereka tidak melakukan perbuatan yang melawan norma hukum, agama, dan susila; keempat, sebagai as a facility on of human interaction yakni hukum berfungsi tidak hanya untuk menciptakan ketertiban, tetapi juga menciptakan perubahan masyarakat dengan cara memperlancar proses interaksi sosial dan diharapkan menjadi pendorong untuk menimbulkan perubahan dalam kehidupan masyarakat. ${ }^{1}$

Termasuk di Negara Republik Indonesia, konstitusi UUD NRI 1945 telah menegaskan didalam pasal 1 ayat (3) yang menyebutkan bahwa "Negara Indonesia adalah negara hukum". Tentu Indonesia seyogyanya berdiri dalam kerangka hukum dalam menjalankan kehidupan bernegara. Pancasila sebagai ideologi negara tentu sebagai sandaran dalam membentuk norma hukum. Karena pancasila sebagai filsafat bangsa dan falsafah negara tentu mengandung arti dalam setiap aspek kehidupan kebangsaan, kemasyarakatan, dan kenegaraan yang berdasarkan kepada nilai Ketuhanan, Kemanusiaan, Persatuan, Kerakyatan, dan Keadilan.

Saat ini pemerintah tengah melakukan berbagai upaya dalam mengejewantahkan kesejahteraan rakyat, sebagaimana paradigma pancasila. Pemerintah berupaya meningkatkan pertumbuhan ekonomi melalui investasi. Dalam mengimpelementasikannya pemerintah mengagas sebuah Rancangan Undang-Undang Omnibus Law yang dengan alasan guna memangkas dan menyederhanakan berbagai regulasi yang dinilai sudah terlalu banyak dan tumpang tindih, terdapat 8.451 aturan di tingkat pusat dan 15.985 peraturan daerah. Dimana hal tersebut membuat pemerintah terkekang dan terbatas ruang geraknya sehingga kecepatan pemerintah dalam mengambil keputusan menjadi terlambat dan kurang tepat Omnibus law adalah suatu Undang-Undang (UU) yang dibuat untuk menyelesaikan isu besar dengan mencabut atau mengubah beberapa UU sekaligus, sehingga menjadi lebih sederhana. Pemerintah sedang menyusun omnibus law yang tujuan akhirnya untuk mendorong pertumbuhan ekonomi nasional.

Namun terjadi polemik dalam proses pembentukkan RUU Omnibus Law ini. Beragam penolakan dari berbagai elemen, utamanya masyarakat. RUU Omnibus Law yang menjadi sorotan ialah Cipta kerja (Ciptaker). Dapat dikatakan bahwa produk hukum omnibus law adalah produk yang tidak partisipatif. Karena merugikan masyarakat utamanya sektor buruh (pekerja). Bentuk kerugian yang pertama terkait dengan dihapuskanya upah minimum yang sebelumnya telah diatur dalam Undang-Undang Nomor 13 Tahun 2003 tentang ketenagakerjaan yang memang dinilai sudah cukup berpihak pada buruh. Hal ini akan menjadi preseden yang buruk dimana pemerintah akan mengatur sistem upah perjam yang secara otomatis akan menghilangkan sistem upah minimum. Sebab tidak menutup kemungkinan dalam praktiknya pengusaha akan sangat mudah untuk menurunkan jam kerja, sehingga pekerja tidak lagi bekerja 40 jam.

Artinya, jika itu masih dilakukan, sama saja dengan kejahatan. Hal lain yang tidak kalah menggegerkan publik ialah ditiadakanya pesangon. Dalam UU No. 13 Tahun 2003 pula mengatur besaran pesangon maksimal 9 bulan dan dapat dikalikan 2 untuk pemutusan hubungan kerja (PHK) jenis tertentu. Ketentuan tersebut akan dihilangkan jika RUU Omnibus Law telah disahkan. Pemerintah dinilai memiliki rencana memangkas

${ }^{1}$ Sirajuddin [et.al]. 2006 Legislatif Drafting metode partisipatif dalam pembentukan peraturan perundang-undangan. Malang: setara press. hlm.2 
pesangon menjadi tunjangan PHK sebesar 6 bulan upah. Selain itu dihilangkanya sanksi pidana terhadap pengusaha pelanggar juga menjadi tamparan keras bagi para kaum buruh. Sanksi pidana bagi pengusaha yang melanggar atau tidak memenuhi hak buruh berpotensi hilang. Sehingga dampak buruknya, pengusaha tidak akan memiliki efek jera atas tindakannya. Sementara itu, pemerintah telah beberapa kali memberikan berbagai bentuk insentif bagi pengusaha. Namun, hal tersebut tidak pernah terjadi kepada kaum pekerja. $^{2}$ Dan yang juga menjadi persoalan adalah pemerintah pusat mencoba mengakuisisi kewenangan pemerintahan daerah lewat rancangan undang-undang omnibus law Pemerintah berencana menghapus wewenang pemerintah daerah (pemda) dalam pengaturan tata ruang. Hal ini diketahui berdasarkan draft Pasal 18 Rancangan Undang-Undang (RUU) Cipta Kerja yang diserahkan pemerintah ke Dewan Perwakilan Rakyat (DPR). Aturan dalam pasal ini merujuk ke Undang-Undang (UU) Nomor 26 Tahun 2007 tentang Penataan Ruang.

Dalam draft aturan baru ini, Pemerintah menghapus sejumlah pasal antara lain mengenai wewenang pemerintah daerah baik provinsi maupun kabupaten/kota dalam penyelenggaraan tata ruang. Secara rinci, wewenang pemda yang dihapus antara lain pengaturan, pembinaan, dan pengawasan terhadap pelaksaaan penataan ruang wilayah provinsi, dan kabupaten/kota. Selain itu, Pemerintah juga menghapus wewenang pemda untuk melaksanakan penataan ruang dan kawasan strategis baik di tingkat provinsi atau kabupaten/kota. Pemda juga tidak dapat melaksanakan kerjasama penataan ruang antar wilayah. Khusus di lingkup provinsi, dalam draft RUU tersebut pemerintah provisni tidak dapat memfasilitasi kerjasama penataan ruang antar kabupaten/kota serta penyusunan petunjuk bidang penataan ruang antar kabupaten/kota.

Oleh karenanya, Pemerintah juga menghapus ketentuan rencana tata ruang, penetapan, dan penataan untuk kawasan strategis kabupaten Selain itu, aturan yang dihapus adalah Pasal 24 dan 27 yang memuat ketentuan rencana rinci tata ruang pada peraturan daerah. Draft ini juga menyatakan jika Pemerintah Pusat mengatur penyelenggaraan penataan ruang. Adapun yang dimaksud dengan Pemerintah Pusat adalah Presiden Republik Indonesia yang dibantu oleh Wakil Presiden dan Menteri. Pada aturan sebelumnya, penyelenggaraan penataan ruang dilaksanakan oleh seorang Menteri. ${ }^{3}$ Dengan digantinya banyak peraturan dalam satu undang-undang Omnibus Law, selain berimplikasi terhadap peraturan pelaksana undang-undang yang diganti, kondisi ini akan memperkokoh sentralisme, dan jelas mengganggu eksistensi otonomi daerah.

\section{HASIL DAN PEMBAHASAN}

\section{Korporatokrasi}

Korporatokrasi adalah sebuah istilah yang merujuk kepada perusahaanperusahaan besar yang mendominasi, bahkan mengendalikan pemerintahan. Ditambah dengan penghancuran banyak undang undang yang dilibas oleh apa yang dikenal dengan Omnibus Law. RUU Omnibus law dibuat lebih untuk memperkuat posisi investor atau pengusaha. Omnibus law perpajakan juga berorientasi pada investasi. ${ }^{4}$ Sehingga hal ini lah yang akan menjadi berbahaya bila kekuatan korporasi mendominasi suatu negara.

2 Abanna, M.S. 2020. 6 Poin Kontroversi Omnibus Law Cipta Lapangan Kerja.

https://www.tagar.id/6-poin-kontroversi-omnibus-law-cipta-lapangan-kerja. Diakses tanggal 27 Februari 2020.

${ }^{3}$ https://properti.kompas.com/read/2020/02/15/163200821/ruu-cipta-kerja-kewenanganpemda-terkait-penataan-ruang-bakal-dihapus. diakses Pada tanggal 2 Maret 2020

${ }^{4}$ https://kronologi.id/2020/02/24/korporatokrasi/ diakses pada tanggal 5 Maret 2020. 
Negara Indonedia seolah kehilangan statusnya sebagai negara demokrasi yang memprioritaskan daulat rakyat, yang ada ialah rakyat disengsarakan dengan hak-hak sipilnya direduksi.

\section{Demokrasi}

Demokrasi secara harfiah disebut dari rakyat, oleh rakyat, dan untuk rakyat. Rakyat tentu pemegang daulat tertinggi di negara demokrasi oleh karna itu sejatinya pembuatan norma hukum hakikatnya harus berpijak pada sendi demokrasi. Selain itu ketika hukum diperankan sebagai alat rekayasa sosial (law as tool of social eigeneering) tak pelak menempatkan peraturan perundang-undangan pada posisi yang sangat penting dalam mengatur tata kehidupan masyarakat. Konsep ini diperkenalkan oleh Roscoe Pound. Mochtar Kusumaatmadja juga mengetengahkan konsep Roscoe Pound tentang perlunya memfungsikan law as tool of social eigeneering di Indonesia. ${ }^{5}$ Mochtar berargumentasi bahwa pendayagunaan hukum sebagai sarana untuk merekayasa masyarakat menurut skenario kebijakan pemerintah (Eksekutif) amatlah diperlukan oleh negara-negara yang sedang berkembang, jauh melebihi kebutuhan negara-negara industri maju yang telah mapan. Negara-negara maju memiliki mekanisme hukum yang telah jalan untuk mengakomodasi perubahan-perubahan dalam masyarakat, sedangkan negara-negara yang berkembang tidaklah demikian. Padahal harapan-harapan dan keinginan masyarakat-masyarakat di negara yang sedang berkembang akan terwujudnya perubahan-perubahan yang membawa perbaikan taraf hidup amatlah besar melebihi harapan-harapan yang diserukan oleh masyarakat-masyarakat di negara maju.

Pembentukan undang-undang tentu menjadi bagian dari aktivitas dalam mengatur masyarakat yang terdiri dari atas gabungan individu-individu manusia dengan segala dimensinya. ${ }^{6}$ Sehingga merancang dan membentuk undang-undang yang dapat diterima masyarakat luas merupakan suatu pekerjaan yang sulit. Kesulitan ini terletak pada kenyataan bahwa kegiatan pembentukan undang-undang adalah suatu bentuk komunikasi antara lembaga yang menetapkan yaitu pemegang kekuasaan legislatif dengan rakyat dalam suatu negara. Kesulitan-kesulitan dalam pembentukan undangundang ini, sekarang lebih dirasakan oleh bangsa Indonesia yang tengah menghadapi berbagai problem sosial secara mendasar pada permasalahan struktural dan kultural yang multi dimensi. Undang-Undang yang akan dibentuk jelas dipengaruhi oleh politik hukum yang merupakan kebijakan resmi dari negara yang berkaitan dengan pemberlakuan hukum. Sehingga tepatlah menempatkan hukum sebagai instrument kesejahteraan masyarakat dan juga sebagai pembahruan sosial, dengan begitu hukum mencerminkan nyawanya ketika keberadaannya sesuai dengan nilai-nilai yang ada di masyarakat.

Namun hukum faktanya tidak selalu singkron dan harmonis dengan harapan masyarakat. Proses pembentukkannya masih saja menuai polemik, potret secara yuridis draft RUU Omnibus Law termaktub didalam pasal 170 RUU Omnibus Law Ciptaker ini memuat materi bahwa Peraturan Pemerintah (PP) diberi kekuasaan untuk mengganti ketentuan dalam UU. Hal ini tentu sangat bertentangan dari yang seharusnya didalam

\footnotetext{
${ }^{5}$ Sirajuddi [et.al] Legislatif Drafting metode partisipatif dalam pembentukan peraturan perundangundangan hlm 3.

${ }^{6}$ Satjipto Rahardjo, Penyusunan Undang-Undang yang Demokratis, Makalah dalam Seminar Mencari Model Ideal Penyusunan Undang-Undang yang Demokratis dan Kongres Asosiasi Sosiologi Hukum Indonesia Fakultas Hukum Universitas Diponegoro Semarang Tanggal 15-16 April 1998, hlm. 3-5.
} 
hierarki perundang-undangan sebagaimana dijabarkan dalam pasal 7 Undang-Undang Nomor 12 Tahun 2011 sebagaimana yang telah diubah menjadi Unang-Undang Nomor 15 Tahun 2019 tentang pembentukkan peraturan perundang-undangan. ${ }^{7}$ Karena peraturan pemerintah berada di bawah jenjang UU. Dengan demikian ketentuan mengenai pasal 170 ayat (1) dan (2) RUU Cipta Lapangan Kerja sangat tidak relevan dari asas penafsiran hukum Lex superiori derogate legi inferiori. Bahwa norma hukum yang lebih tinggi sejatinya mengenyampingkan norma hukum yang lebih rendah. Hal ini juga sejalan dengan stufenbau theory yang dikenalkan oleh Hans Kelsen, bahwa dalam sistem hukum, ialah sistem berjenjang secara hierarki. Dimana kaidah norma hukum yang lebih rendah berpegang kepada norma hukum yang lebih tinggi, dan juga norma hukum yang lebih tinggi berpegang kepada norma hukum yang mendasar (pure theory of law). ${ }^{8}$

\section{Eksistensi Otonomi Daerah Direduksi}

RUU Omnibus Law Ciptaker berpotensi mengebiri eksistensi otonomi daerah, padahal kita ketahui bahwa pilihan atas bentuk negara kesatuan dengan sistem otonomi dan desentralisasi menuntut pemerintah pusat yang dipimpin oleh Presiden sebagai kepala negara sekaligus kepala pemerintahan untuk secara konsisten bersedia berbagi kekuasaan dengan satuan pemerintahan daerah yang dipimpin oleh kepala daerah yang dipilih langsung oleh rakyat. Di sisi lain juga pemerintah daerah dituntut untuk mandiri dan mampu melakukan inovasi sebagai konsekuensi keleluasaan dalam penyelenggaraan pemerintahan daerah. ${ }^{9}$

Polemik dalam pasal 251 RUU Ciptaker, bahwa Perda provinsi hingga Perda kabupaten/kota serta peraturan kepala daerah mulai dari provinsi hingga kabupaten dan kota dapat dibatalkan apabila bertentangan dengan peraturan perundang-undangan yang lebih tinggi. Peraturan-peraturan pada level daerah tersebut dapat dicabut dan dinyatakan tidak berlaku langsung melalui Peraturan Presiden. Jika Pemda masih bersikukuh memberlakukan peraturan yang telah dibatalkan melalui Perpres oleh presiden, Pemda bisa dikenai sanksi administratif dan sanksi penundaan evaluasi rancangan Perda. Sanksi administratif yang dimaksud yakni tidak dibayarkannya hak keuangan kepala daerah dan anggota DPRD selama tiga bulan.

Secara historis, klausul sejenis sudah pernah tertuang dalam UU Pemda dalam pasal yang sama yakni Pasal 251. Dahulu, Perda povinsi dan peraturan gubernur yang bertentangan dengan ketentuan perundang-undangan yang lebih tinggi dapat dicabut secara langsung oleh Menteri Dalam Negeri. Apabila terdapat Perda kabupaten/kota ataupun peraturan kepala daerah yang bertentangan dengan peraturan yang lebih tinggi, maka Gubernur setempat selaku perwakilan pemerintah pusat yang berhak membatalkan Perda tersebut. Ketentuan-ketentuan tersebut pada akhirnya dibatalkan oleh dua Putusan Mahkamah Konstitusi (MK) yakni Putusan No. 137/PUUXIII/2015 dan Putusan No. 66/PUU-XIV/2016.

Menurut MK, kewenangan Menteri Dalam Negeri ataupun Gubernur untuk mencabut Perda dan Peraturan Kepala Daerah adalah inkonstitusional dan bertentangan dengan Pasal 18 Ayat 6, Pasal 28D Ayat 1, dan Pasal 24A Ayat 1 UUD 1945. Dengan adanya dua putusan tersebut, Mahkamah Agung (MA) menjadi institusi tunggal yang berwenang untuk membatalkan peraturan daerah baik Perda maupun Peraturan Kepala Daerah.

7 Undang-Undang Nomor 12 tahun 2011 Sebagaimana yang telah diubah menjadi Undang-Undang Nomor 15 tahun 2019 tentang pembentukkan peraturan perundang-undangan.

${ }^{8}$ Journal for Constitusional Theory and Philosophy of Law dan Pure Theory Of Law Hans Kelsen.

${ }^{9}$ Sirajuddin, Kabinet Presidensial Dan Penguatan Inovasi Pemerintahan Daerah. Jurnal Ilmiah 
Artinya, pemerintah pusat kembali menghidupkan pasal yang telah dibatalkan oleh MK pada 2015 dan $2016 .{ }^{10}$

Polemik juga muncul dari sisi perizinan. Melalui UU Cipta Kerja, pemerintah merevisi Pasal 350 dari UU Pemda dan dalam pasal terbaru dituangkan bahwa pelayanan berizinan berusaha wajib menggunakan sistem perizinan elektronik yang dikelola oleh pemerintah pusat. Kepala daerah hanya diberi kewenangan untuk mengembangkan sistem pendukung pelaksanaan sistem perizinan berusaha sesuai dengan standar yang ditetapkan pemerintah pusat. Lagi-lagi, terdapat ancaman sanksi kepada pemda yang enggan melaksanakan ketentuan tersebut. Jika teguran tertulis dari pemerintah pusat tidak digubris oleh kepala daerah sebanyak dua kali berturut-turut, pemerintah pusat dapat mengambil alih kewenangan perizinan berusaha dari gubernur. Gubernur juga diberi kewenangan untuk mengambil alih kewenangan perizinan berusaha dari bupati/wali kota.

UU Cipta Kerja juga menyisipkan satu pasal baru dalam UU Pemda yakni Pasal 402A. Dalam pasal tersebut, pembagian urusan pemerintahan konkuren antara pemerintah pusat dengan pemda disebut harus dibaca dan dimaknai sesuai dengan ketentuan yang diatur dalam UU Cipta Kerja. Ketika ditinjau lebih lanjut, Bisnis tidak menemukan penjelasan dari pemerintah mengenai klausul baru dari Pasal 402A tersebut. Seiring dengan tergerusnya kewenangan pemerintah daerah, kewenangan pemerintah pusat pun semakin absolut diperkuat dengan klausul-klausul baru dari UU Cipta Kerja. Pada Pasal 164, tertulis jelas bahwa dengan berlakunya UU Cipta Kerja, maka kewenangan menteri, kepala lembaga, ataupun pemda yang telah ditetapkan dalam UU Cipta Kerja wajib dimaknai sebagai kewenangan presiden. ${ }^{11}$

Sektor lingkungan juga turut terusik dengan adanya RUU Omnibus Law pertambangan mineral dan Batubara termasuk dalam sasaran pemerintah dalam menyusun Rancangan UU Cipta Kerja. Salah satu yang diajukan adalah tidak adanya batas luas wilayah produksi pertambangan mineral dan Batubara. Perubahan aturan luas produksi itu tertuang dalam Pasal 83 huruf c RUU Cipta Kerja. Hal ini sangat rawan sekali timbul konflik antara perusahaan dengan masyarakat dan membuat masyarakat tercerabut dari ruang hidupnya.

Perusahaan pertambangan akan dengan mudah mengajukan izin perluasan wilayah produksi pertambangan walaupun wilayah tersebut merupakan daerah pemukiman masyarakat. Artinya dengan adanya Omnibus Law tersebut, karena tidak adanya batasan lahan pengajuan produksi pertambangan mineral dan batubara pengusiran terhadap warga atas nama investasi bisa saja terjadi.

Selain itu, kajian dari Wahana Lingkungan Hidup Indonesia (WALHI) menunjukkan, penghapusan izin lingkungan dalam draft Omnibus Law RUU Cipta Kerja dalam rangka memudahkan pelaku usaha memperoleh persetujuan lingkungan. Izin lingkungan yang diatur dalam Pasal 40 ayat 1 Undang-undang Nomor 32 Tahun 2009 tentang Perlindungan dan Pengelolaan Lingkungan Hidup disapu dalam draf RUU Ciptaker. ${ }^{12}$ Hal yang paling disoroti adalah soal sanksi administrasi kepada korporasi yang melakukan pembakaran lahan dan hutan diserahkan ke pemerintah. Selain itu, Omnibus Law Ciptaker ini juga bakal merugikan masyarakat sipil. Khususnya hak-hak rakyat akan

\footnotetext{
${ }^{10}$ Lihat Putusan Mahkamah Konstitusi No. 137/PUU-XIII/2015 dan No. 66/PUU-XIV/2016.

11 https://ekonomi.bisnis.com/read/20200214/9/1201473/duh-omnibus-law-berpotensiredupkan-otonomi- daera. diakses pada tanggal 3 Maret 2020.

12 https://www.cnnindonesia.com/nasional/20200221013705-20-476636/walhi-nilai-omnibuslaw-rampas-hak-rakyat-atas-lingkungan. diakses pada tanggal 27 Februari 2020.
} 
sumber daya alam. Hak warga negara untuk mengajukan gugatan terhadap kegiatan yang merusak lingkungan juga dikebiri. Dalam draft omnibus law RUU Omnibus Law Ciptaker, hanya orang yang terdampak langsung dari kerusakan lingkungan itu yang bisa mengajukan gugatan. ${ }^{13}$

SKEMA 1

KERANGKA ALUR PIKIRAN RUU OMNIBUS LAW

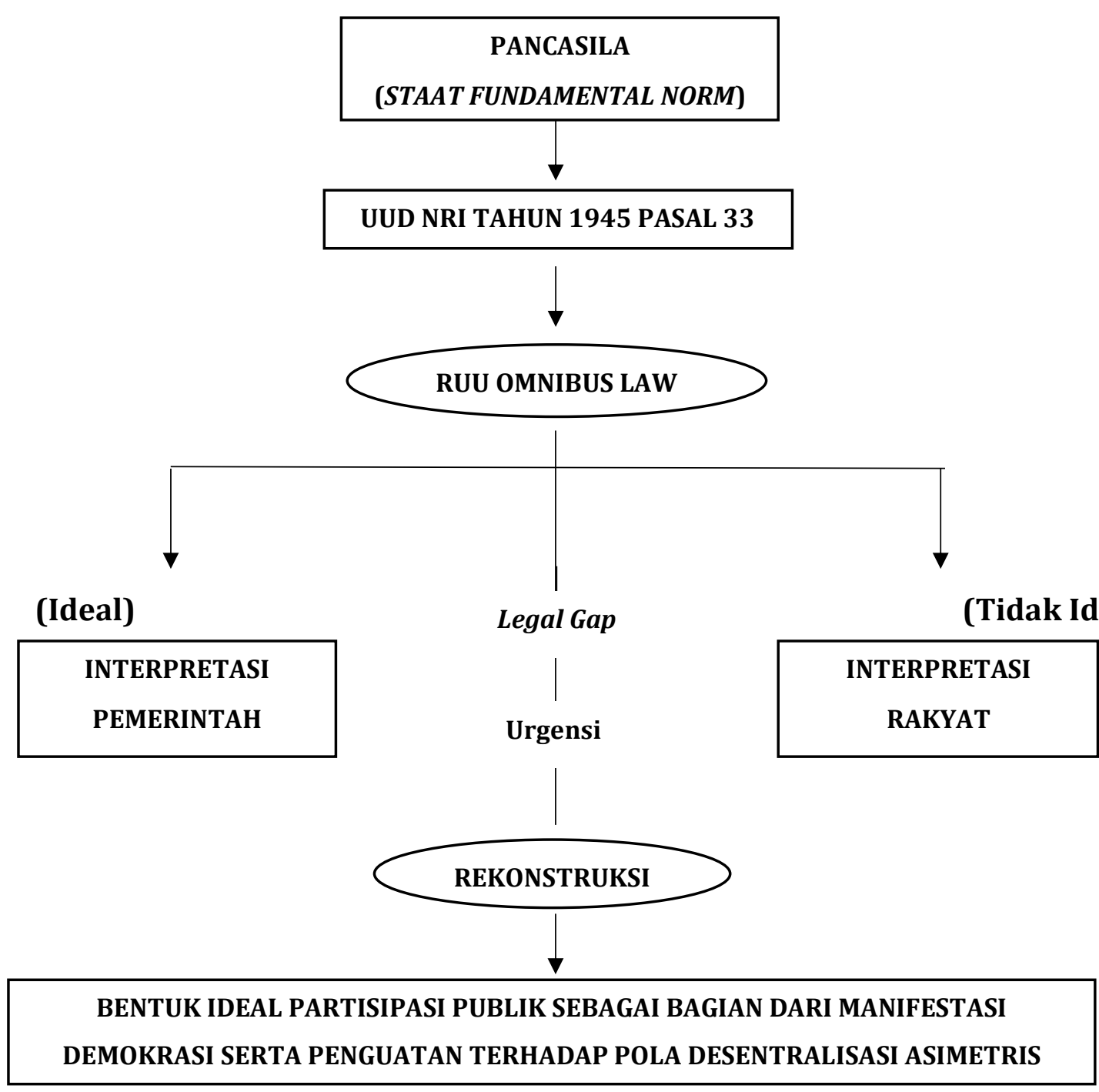

Pada skema alur kerangka diatas dapat dipahami tujuan pemerintah dalam mengimplementasikan prinsip kesejahteraan rakyat sebagaimana amanat Pancasila dan UUD NRI tahun 1945. Sebagaimana pasal 33 menjelaskan bahwa SDA Indonesia dikuasai oleh negara dan dipergunakkan sebesar-besarnya untuk kemakmuran rakyat. Namun dibalik tujuan baik pemerintah dengan adanya produk norma RUU Omnibus Law memang dinggap ideal oleh pemerintah untuk membuka ruang investasi agar investor datang untuk membuka lapangan kerja, sehingga hal ini dianggap menguntungkan dalam pertumbuhan ekonomi. Rakyat menginterpretasikan berbeda, upaya pemerintah untuk

13 Ibid. 
mensejahterakan rakyat justru faktanya berpotensi mereduksi hak-hak mereka, utamanya kaum buruh (pekerja). Dan juga dalam pembahasan rancangan undang-undang ini sangat minim sekali partisipasi publik. Pekerja adalah bagian dari masyarakat dan juga sebagai pemangku kepentingan (Stakeholders). Sehingga sudah seharusnya dilibatkan dalam proses pembahasan RUU Omnibus Law ini. Namun faktanya dalam pembahasan draft RUU Omnibus Law lebih didominasi oleh Pemerintah dan pengusaha seloah memberi keuntungan sebesar-besarnya bagi korporasi dan pemilik modal (kapitalis) serta mengabaikan hak-hak rakyat. Sehingga tepat rasanya menegasikan Negara Republik Indonesia dikuasai oleh Korporatokrasi (pemerintahan perusahaan) yaitu sebuah istilah yang mengacu pada bentuk pemerintahan dimana kewenangan telah didominasi atau beralih dari negara kepada perusahaan-perusahaan besar sehingga petinggi pemerintah dipimpin secara sistem afiliasi korporasi (perusahaan). ${ }^{14}$

Proses privatisasi perusahaan publik umumnya menjadi permulaan bentuk pemerintahan ini, sebab negara kehilangan kewenangan peraturan dalam ekonomi dan pelayanan publik oleh karena lembaga bisnis yang berperan besar pada kebijakan. Semakin teguh rasanya rezim korporatokrasi ini berdiri. Negara berdiri bersama kapitalis, sementara rakyat diperlakukan bagaikan sapi perah. Inilah fakta perselingkuhan penguasa dan pengusaha. Negara hanya berperan sebagai regulator, penguasa sesungguhnya adalah korporasi yang berlindung di balik pemerintah. UndangUndang dibuat hanya untuk memberi keleluasaan bagi pengusaha menguasai perekonomian negara. Dalam hal ini, peran negara mandul dan lemah. ${ }^{15}$ Lantas ruang publik dalam prinsip demokrasi seakan terdegradasi, rakyat tidak lagi dianggap penting dalam pengambilan keputusan.

\section{PENUTUP}

Berdasarkan pembahasan diatas, dapat disimpulkan sebagai berikut:

1. Pemerintah dalam hal ini Presiden selaku eksekutif dan DPR sebagai legislatif perlu melakukan kajian ulang yang lebih komprehensif lagi terhadap RUU Omnibus Law sekaligus menjadi urgensi juga untuk membuka ruang dialog berbagai arah dengan melibatkan seluruh pemangku kepentingan (Stakeholders). Mengingat prinsip keterbukaan perlu diutamakan sebagaimana termaktub didalam pasal 5 UndangUndang Nomor 12 tahun 2011 sebagaimana yang telah diubah menjadi UndangUndang Nomor 15 tahun 2019 tentang pembentukkan peraturan perundangundangan. Pemerintah dan DPR harus mewujudkannya demi perwujudan dari Negara demokrasi yang menghargai partisipasi publik. Dengan begitu produk norma hukum yang dihasilkan akan menghasilkan kedayagunaan bagi seluruh pihak dan akan dapat berlaku efektif serta responsif.

2. Pemerintah pusat juga tidak boleh sewenang-wenang dalam mengakuisisi kewenangan dari pemerintah daerah karena otonomi daerah dengan pola desentralisasi seharusnya memberikan kewenangan penuh kepada daerah untuk mengurusi rumah tangganya sendiri. Dan pemerintahan pusat seharusnya juga konsistant dalam berbagi kekuasaan dengan pemerintahan daerah. Karena pemerintah pusat tentu juga terbantu oleh pemerintahan daerah dalam melaksanakan pengembangan dan pembangunan di daerah. Pembahasan RUU Omnibus Law ini juga harus turut serta melibatkan Pemerintah Daerah agar termanifestasikan kesepakatan

${ }^{14}$ https://id.wikipedia.org/wiki/Korporatokrasi diakses pada tanggal 2 Maret 2020.

15 https://kronologi.id/2020/02/24/korporatokrasi/ diakses pada tanggal 2 Maret 2020. 
(consensus) dari komunikasi dua arah antara Pemerintah Pusat dan Pemerintah Daerah, sehingga akan bertitik akhir kepada sinergitas birokrasi pusat dan daerah.

\section{DAFTAR PUSTAKA}

\section{Buku:}

Bhenyamin Hoessein, 2005. "Hubungan Kewenangan Pusat dan Daerah" dalam Soetandyo Wignjosoebroto, dkk, 2005. Pasang Surut Otonomi Daerah : Sketsa Perjalanan 100 Tahun, Jakarta : Yayasan Tifa dan ILD

Sirajuddin [et.al]. 2006. Legislatif Drafting metode partisipatif dalam pembentukan peraturan perundang-undangan. Malang: setara press.

\section{Artikel Jurnal:}

Alfaris, M. R., 2018. Peran Dan Tindakan Dewan Perwakilan Daerah Dalam Konteks Kekuasaan Dan Kewenangan Yang Merepresentasikan Rakyat Daerah. Conference on Innovation and Application of Science and Technology (CIASTECH), p. 212.

Journal for Constitusional Theory and Philosophy of Law dan Pure Theory Of Law Hans Kelsen.

Sirajuddin, Kabinet Presidensial Dan Penguatan Inovasi Pemerintahan Daerah.

Satjipto Rahardjo, Penyusunan Undang-Undang yang Demokratis, Makalah dalam Seminar Mencari Model Ideal Penyusunan Undang-Undang yang Demokratis dan Kongres Asosiasi Sosiologi Hukum Indonesia Fakultas Hukum Universitas Diponegoro Semarang Tanggal 15-16 April 1998, hlm. 3-5.

\section{Peraturan Perundang-Undangan :}

Undang- Undang Nomor 15 tahun 2019 Perubahan atas Undang-Undang Nomor 12 tahun 2011 tentang Pembentukkan Peraturan Perundang-undangan.

Putusan Mahkamah Konstitusi No. 137/PUU-XIII/2015 dan No. 66/PUU-XIV/2016.

\section{Internet:}

Abanna, M.S. 2020. 6 Poin Kontroversi Omnibus Law Cipta Lapangan Kerja. https://www.tagar.id/6-poin-kontroversi-omnibus-law-cipta-lapangan-kerja. Diakses tanggal 27 Februari 2020.

https://properti.kompas.com/read/2020/02/15/163200821/ruu-cipta-kerjakewenangan-pemda-terkait-penataan-ruang-bakal-dihapus. diakses tanggal 2 Maret 2020.

https://id.wikipedia.org/wiki/Korporatokrasi diakses pada tanggal 2 Maret 2020. https://kronologi.id/2020/02/24/korporatokrasi/ diakses pada tanggal 2 Maret 2020. https://kronologi.id/2020/02/24/korporatokrasi/ diakses pada tanggal 5 Maret 2020. https://ekonomi.bisnis.com/read/20200214/9/1201473/duh-omnibus-lawberpotensi-redupkan-otonomi- daerah diakses pada tanggal 3 Maret 2020

https://www.cnnindonesia.com/nasional/20200221013705-20-476636/walhi-nilaiomnibus-law-rampas-hak-rakyat-atas-lingkungan, diakses pada tanggal 27 Februari 2020. 
